\title{
Dynamic Spillovers between Oil and Stock Markets: New Approaches at Spillover Index
}

\author{
Yen-Hsien Lee ${ }^{1}$, Ting-Huei Liao ${ }^{2}$, Ya-Ling Huang ${ }^{3} \&$ Tzu-Ling Huang ${ }^{1}$ \\ ${ }^{1}$ Department of Finance, Chung Yuan Christian University, Taiwan \\ ${ }^{2}$ Department of Banking and Finance, Tamkang University, Taiwan \\ ${ }^{3}$ Department of Golden-Ager Industry Management, Chaoyang University of Technology, Taiwan \\ Correspondence: Ya-Ling Huang, Department of Golden-Ager Industry Management, Chaoyang University of \\ Technology, 168, Jifeng E. Rd., Wufeng District, Taichung 41349, Taiwan. Tel: 886-4-2332-3000\#7832. E-mail: \\ ylhuang@cyut.edu.tw
}

Received: March 7, 2015

Accepted: April 13, 2015

Online Published: April 17, 2015

doi:10.5430/ijfr.v6n2p178

URL: http://dx.doi.org/10.5430/ijfr.v6n2p178

\begin{abstract}
This study investigates the spillover effects of return and volatility between Brent oil market and stock markets (comparing oil market with both stock markets of oil-exporting and oil-importing countries together and individually) by spillover index. We further use parametric and nonparametric methods to examine the major events' impact on dynamic of return and volatility spillover indices between Brent oil market and stock markets. The empirical evidence indicates oil-exporting countries have had significant impact on returns and volatilities of oil-importing countries, which stock market in Canada is a dominant net sender and stock market in Netherland is a dominant net receiver. Second, the oil market spillover on oil-exporting markets more than oil-importing markets in terms of both returns and volatilities, especially oil market had a high impact on Canada. Moreover, stock market in Canada had dominant spillover on other markets. We conjecture that Brent oil market indirect spillover on other countries through Canada. Finally, the result shows that the dynamics of return and volatility spillovers burst significantly during the major events.
\end{abstract}

Keywords: Brent oil market, stock returns, volatility, spillover index

\section{Introduction}

The return and volatility of spillovers between oil prices and stock markets has recently been developed. Lots of empirical research has studied the interactions between oil and stock markets, indicating the return and volatility transmission mechanisms enable portfolio managers and policymakers to design accurate asset pricing models and make better portfolio allocation decisions. (Note 1) Therefore, this study applies the newly generalized version of the spillover index, and extend the relationship between the oil market and stock markets. We analyze the spillover effects of return and volatility between Brent oil market and stock markets, comparing Brent oil with both stock markets of oil-exporting and oil-importing countries together and individually. Based on the stock-oil net spillovers contribution evaluate the oil market is exactly a net sender or a net receiver in a system of spillovers composed of oil and stock markets. Finally, we summarized the major events which affecting the oil and stock markets during the period of the study, and test the difference of spillover between before event and after event.

The research study of oil on stock markets can be divided into oil-exporting and importing countries. Regarding to the relationship between oil prices and oil-exporting countries, much of the research show the bilateral links between oil price and oil-exporting countries (Note 2). Moreover, the literature focused on oil-importing countries find significant spillovers between oil and oil-importing countrie. (Note 3) However, few studies look into both oil-exporting and importing countries. Lescaroux and Mignon (2008) show evidence of the key role played by the oil market on oil-exporting and oil-importing stock markets, especially for oil-exporting countries. Park and Ratti (2008) find that positive oil price shocks cause positive returns for the oil-exporting countries, whereas the opposite happens to the rest of the oil-importing countries. Distinguishing the linkage between Brent oil prices and stock markets between oil-exporting and importing countries for comparison purposes and come to understand how they react to oil price shocks. This paper investigates the relationship between Brent oil prices and stock markets among oil-exporting 
and oil-importing countries.

Early work on spillovers, there are two econometric methodology mostly study spillover effects, the GARCH family and spillover index measures. GARCH family is most commonly used by study. (Note 4) However, the spillover index provided by Diebold and Yilmaz $(2009,2012)$ has several advantages over the methods above. (Note 5) The applications of spillover index a very wide range. (Note 6) Few studies have reported dynamic spillover relationships between Brent oil prices and stock markets among oil-exporting and oil-importing countries; thus, the purpose of this study is to provide further.

This paper makes a more detailed definition of spillover between oil and stock markets. First, we defined oil spillover effects indicates the directional spillovers received by Brent oil from all other markets. Second, the directional spillovers transmitted by Brent oil to all other markets can be defined as stock spillover effects. Third, stock-oil net spillovers can be indicated whether Brent oil is a net sender or a net receiver in a system includes stock markets and the oil market. Compared with the previous method, spillover index is now possible to assess the net spillovers of a system composed of stock markets and the oil market.

In addition, this paper take into the events which origins of oil prices shocks, and provides detailed dynamic of return and volatility spillovers between Brent oil price and stock markets returns. The major world turmoil events spread from the country of origin to other countries in the world, it is important to investigate return and volatility spillovers across countries during the oil price change. The oil price movements show significant peaks and troughs during the major events. The Brent oil prices fell by almost 50\% in 1997 Asian crisis, in 2007 to 2006, where prices fell by 40\% due to the rising demand for Chinese economic growth, and in 2008, where prices fell by more than $70 \%$ and peak more than $60 \%$ in 2009 result from the Global financial crisis. (Note 7) Our paper different from the previous literature in that we use parametric and nonparametric method to test the difference of spillover between before event and after event. While dynamic of return and volatility spillovers burst significantly during the major events.

The rest of the paper is organized as follows. Section 2 briefly presents data and methodology. Section 3 presents the results of the empirical analysis, while section 4 provides summary conclusions.

\section{Data and Methodology}

\subsection{Data Description}

The data employed in this study includes the daily Brent oil prices and stock market indices. The sample consists of three oil-exporting countries (Canada, Mexico and Brazil) and three oil-importing countries (USA, Germany and Netherlands) from January 5, 1994 to December 28, 2012 (a total of 4142 daily observations in each index). According to EIA estimates, the selected countries are the following three criteria by Filis et al. (2011). (Note 8) The stock market indices are: S\&P/TSX Comp (Canada), MXICP 35 (Mexico), Bovespa Index (Brazil), Dow Jones Industrial (USA), DAX 30 (Germany) and AEX General Index (Netherlands). All prices from oil and stock markets are obtained from Datastream. This paper according to main events that took place in the period and split the data into eight sub-periods, using parametric and nonparametric method to examine that the major events impact on dynamics of return and volatility spillovers between Brent oil market and stock markets.

\subsection{Measuring Return and Volatility}

The idea of the investigation is that our data are generally non-stationary, daily return defined as:

$$
\mathrm{R}_{\mathrm{t}}=\left(\ln \mathrm{P}_{\mathrm{t}}-\ln _{\mathrm{t}-1}\right) \times 100
$$

where $\mathrm{P}_{\mathrm{t}}$ is the Brent oil price at time $\mathrm{t}$, with $t=1,2, \ldots, T$, and $\mathrm{ln}$ the natural logarithm. (Note 9) The volatility assumes the mean and conditional variance specification of a GARCH $(1,1)$ process of the return be modeled by the following system of equations

$$
\begin{gathered}
R_{t}=\beta_{1}+\beta_{2} R_{t}+\varepsilon_{t} \\
\varepsilon_{t} \sim N\left(0, \sigma_{t}^{2}\right) \\
\sigma_{\mathrm{t}}^{2}=\alpha_{0}+\alpha_{1} \varepsilon_{\mathrm{t}-1}^{2}+\beta_{1} \sigma_{\mathrm{t}-1}^{2}
\end{gathered}
$$

where $\varepsilon_{\mathrm{t}-1}^{2}$ is the error term, $\sigma_{\mathrm{t}-1}^{2}$ is variance at time $t-1$.

\subsection{Measuring Spillover Index}

Consider covariance stationary $\mathrm{N}$ variable $\operatorname{VAR}(\mathrm{p})$

$$
\mathrm{R}_{\mathrm{t}}=\sum_{\mathrm{i}=1}^{\mathrm{p}} \Phi_{\mathrm{i}} \mathrm{R}_{\mathrm{t}-\mathrm{i}}+\varepsilon_{\mathrm{t}}, \mathrm{t}=1,2, \ldots, \mathrm{T}
$$

where $R_{t}=\left(R_{1 t}, R_{2 t}, \ldots, R_{N t}\right)^{\prime}$ is a $(N \times 1)$ vector of endogenous variables, $\Phi_{i}$ is a $(N \times N)$ parameter matrix, $\varepsilon_{t}$ 
is the vector of error with zero mean and the covariance matrix $\sum$. Assuming $\mathrm{R}_{\mathrm{t}}$ is covariance stationary, then there exists moving average representation and is given by

$$
\mathrm{R}_{\mathrm{t}}=\sum_{\mathrm{i}=0}^{\infty} A_{\mathrm{i}} \varepsilon_{\mathrm{t}-\mathrm{i}}, \mathrm{t}=1,2, \ldots, \mathrm{T}
$$

where the $(\mathrm{N} \times \mathrm{N})$ coefficient matrices $A_{i}$ obey a recursion of the form

$$
A_{i}=\Phi_{1} A_{i-1}+\Phi_{2} A_{i-2}+\cdots+\Phi_{p} A_{i-p}, i=1,2, \ldots
$$

with $A_{0}=I_{n}$ and if $A_{i}=0$ for $i<0$.

The Koop et al. (1996), and Pesaran and Shin (1998) (the KPPS hereafter) H-step-ahead forecast error variance decomposition is computed as

$$
\theta_{\mathrm{ij}}^{\mathrm{g}}(\mathrm{H})=\frac{\sigma_{\mathrm{ii}}^{-1} \sum_{\mathrm{h}=0}^{\mathrm{H}-1}\left(\mathrm{e}_{\mathrm{i}}^{\prime} \mathrm{A}_{\mathrm{h}} \sum \mathrm{e}_{\mathrm{j}}\right)}{\sum_{\mathrm{h}=0}^{\mathrm{H}} \mathrm{e}_{\mathrm{i}}^{\prime} \mathrm{A}_{\mathrm{h}} \sum \mathrm{A}_{\mathrm{h}}^{\prime} \mathrm{e}_{\mathrm{i}}}, \mathrm{i}, \mathrm{j}=1,2, \ldots, \mathrm{N}
$$

where $\Sigma$ is the variance matrix for the error vector $\varepsilon, \sigma_{\mathrm{ii}}$ is the standard deviation of the error term of the ith market, and $e_{i}$ is an $(\mathrm{N} \times 1)$ vector with one as the ith elements and 0 elsewhere. Diebold and Yilmaz defined "own variance shares" which are indicated by the fraction of the H-step ahead forecast error variances in forecasting $R_{i}$ due to shocks in $R_{i}$, for $\mathrm{i}=1,2, \ldots, \mathrm{N}$, and "cross variance shares", or spillovers, to be fraction of the H-step ahead error variances in forecasting $R_{i}$ due to shocks to $R_{j}$, for $(\mathrm{i} \neq \mathrm{j})$.

To obtain a unit sum of each row of the variance decomposition, each entry of the variance decomposition matrix is normalized, so that construction the decomposition including own shocks in each market equal to one. According to the characteristics of generalized VAR, $\sum_{\mathrm{j}=1}^{\mathrm{N}} \theta_{\mathrm{ij}}^{\mathrm{g}}(\mathrm{H}) \neq 1$, then normalize each entry of the variance decomposition matrix by the row, as follows

$$
\tilde{\theta}_{\mathrm{ij}}^{\mathrm{g}}(\mathrm{H})=\frac{\theta_{\mathrm{ij}}^{\mathrm{g}}(\mathrm{H})}{\sum_{\mathrm{j}=1}^{\mathrm{N}} \theta_{\mathrm{ij}}^{\mathrm{g}}(\mathrm{H})}
$$

where $\sum_{\mathrm{j}=1}^{\mathrm{N}} \tilde{\theta}_{\mathrm{ij}}^{\mathrm{g}}(\mathrm{H})=1$ and $\sum_{\mathrm{i}, \mathrm{j}=1}^{\mathrm{N}} \tilde{\theta}_{\mathrm{ij}}^{\mathrm{g}}(\mathrm{H})=\mathrm{N}$

Using these results, the spillover index is constructed as follow:

1. Total spillovers:

$$
S^{g}(H)=\frac{\sum_{i, j=1}^{\mathrm{N}} \widetilde{\theta}_{\mathrm{ijj}}^{\mathrm{g}}(\mathrm{H})}{\sum_{\mathrm{i}, \mathrm{j}=1}^{\mathrm{N}} \widetilde{\theta}_{\mathrm{ij}}^{\mathrm{g}}(\mathrm{H})} \times 100=\frac{\sum_{\substack{\mathrm{i}, \mathrm{j}=1 \\ \mathrm{i} \neq \mathrm{j}}}^{\mathrm{N}} \widetilde{\theta}_{\mathrm{i} j}^{\mathrm{g}}(\mathrm{H})}{\mathrm{N}} \times 100
$$

where $\mathrm{i}=($ Brent oil and stock markets $)$ and $\mathrm{j}=($ Brent oil and stock markets). The index measure the contributions from the spillovers of volatility shocks across stock and oil markets to the total forecast error variance.

2. Directional spillovers:

The directional spillovers allow us investigate both magnitude and direction of the spillover, the result of variance composition do not hinge on the sequence of the variable. The directional spillovers received by variable i from all other variables $\mathrm{j}$ are defined as

$$
S_{j \rightarrow i}^{g}(H)=\frac{\sum_{j=1}^{N} \tilde{\theta}_{i j}^{g}(H)}{i \neq j} \times 100
$$

where $\mathrm{i}=$ (Brent oil and stock markets) and $\mathrm{j}=($ Brent oil and stock markets). If $\mathrm{i}=$ Brent oil and $\mathrm{j}=$ stock markets, we can defined as oil spillover effects, indicated the directional spillovers received by Brent oil from all other markets.

Similarly, the directional spillovers transmitted by variable $i$ to all other variables $\mathrm{j}$ as

$$
S_{i \rightarrow j}^{g}(H)=\frac{\substack{j=1 \\ i \neq j} \widetilde{\theta}_{i j}^{\mathrm{g}}(H)}{\sum_{j=1}^{\mathrm{N}} \widetilde{\theta}_{\mathrm{ij}}^{\mathrm{g}}(\mathrm{H})} \times 100
$$

where $\mathrm{i}=$ (Brent oil and stock markets) and $\mathrm{j}=($ Brent oil and stock markets). If $\mathrm{i}=$ Brent oil and $\mathrm{j}=$ stock markets, we can defined as stock spillover effects, indicated the directional spillovers transmitted by Brent oil to all other 
markets.

3. Net spillovers

We obtain the net spillovers from variable $\mathrm{i}$ to all other variables j by subtracting Eq. (11) and Eq. (12) as

$$
\mathrm{S}_{\mathrm{i}}^{\mathrm{g}}(\mathrm{H})=\mathrm{S}_{\mathrm{i} \rightarrow j}^{\mathrm{g}}(\mathrm{H})-\mathrm{S}_{\mathrm{j} \rightarrow \mathrm{i}}^{\mathrm{g}}(\mathrm{H})
$$

where $\mathrm{i}=$ (Brent oil and stock markets) and $\mathrm{j}=$ (Brent oil and stock markets). when $\mathrm{i}=$ Brent oil and $\mathrm{j}=$ stock markets, we can defined as stock-oil net spillovers, indicated whether Brent oil is a net sender $\left(\mathrm{S}_{\mathrm{i}}^{\mathrm{g}}(\mathrm{H})>0\right)$ or a net receiver $\left(\mathrm{S}_{\mathrm{i}}^{\mathrm{g}}(\mathrm{H})<0\right)$ in a system includes stock markets and the oil market.

\section{Empirical Results}

\subsection{Summary Statistics and Unit Root Test}

Table 1 presents descriptive statistics of oil price and stock markets returns. The mean of all oil-exporting countries are higher than oil-importing countries. Brazil exhibit the higher mean and higher standard deviation (2.53), which indicates it has high return and high risk. Most of the equity index series are negatively skewed (except Mexico and Brazil), whereas kurtosis statistics indicate fatter tails for all series. The Jarque-Bera test statistics imply that probability distributions are also non-normal.

Table 1. Descriptive statistics of returns series

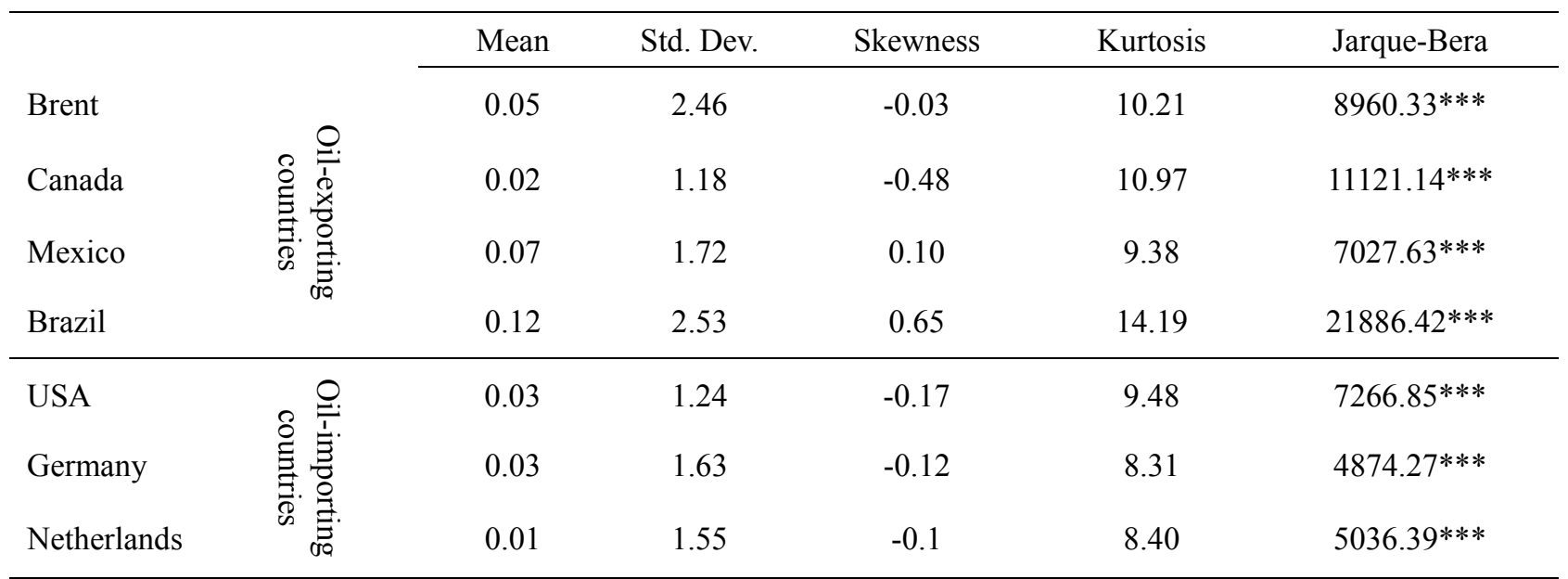

Note: $* * *$ indicate the significant at $1 \%$ level.

We used two traditional unit root tests, namely the augmented Dickey-Fuller (ADF) test and the Phillips-Perron (PP) test. Table 2 presented the result of unit root test. First, in panel A we conduct the tests using natural logarithms of the levels of all series. We find that all of these variables cannot be rejected for levels, all series are non-stationary. Thus, we conducted analysis with first difference on the oil price and stock markets in panel B. The result show all series in first differences reject the null hypothesis at the $1 \%$ significance level, imply all series in first differences are stationary.

Table 2. Unit root tests

\begin{tabular}{lcccccc}
\hline \multicolumn{1}{c}{ Panel A. ADF test results } & \multicolumn{3}{c}{ Levels } & \multicolumn{3}{c}{ First-difference } \\
\cline { 2 - 7 } \multicolumn{1}{c}{ Variables } & C & C\&T & Non & C\&T & C & Non \\
\hline Brent & -0.70 & -2.69 & 0.56 & $-61.69 * * *$ & $-61.69 * * *$ & $-61.68^{* * *}$ \\
Canada & -1.45 & -2.52 & 0.57 & $-63.77 * * *$ & $-63.77 * * *$ & $-63.76^{* * *}$ \\
Mexico & 0.94 & -1.79 & 2.52 & $-61.46^{* * *}$ & $-61.49^{* * *}$ & $-61.38^{* * *}$ \\
Brazil & -0.80 & -2.49 & 0.63 & $-64.48^{* * *}$ & $-64.47 * *$ & $-64.46^{* * *}$ \\
USA & -1.98 & -2.45 & 0.72 & $-69.14^{* * *}$ & $-69.14 * * *$ & $-69.13^{* * *}$
\end{tabular}




\begin{tabular}{lcccccc} 
Germany & -1.58 & -2.12 & 0.47 & $-46.96^{* * *}$ & $-46.95 * * *$ & $-62.71 * * *$ \\
Netherlands & -2.05 & -2.69 & -0.88 & $-61.46^{* * *}$ & $-61.46^{* * *}$ & $-61.47 * * *$ \\
\hline Panel B. PP test results & & & & & & \\
\hline Brent & -0.77 & -2.81 & 0.51 & $-61.66^{* * *}$ & $-61.66^{* * *}$ & $-61.65 * * *$ \\
Canada & -1.41 & -2.48 & 0.65 & $-63.88^{* * *}$ & $-63.87 * * *$ & $-63.87 * * *$ \\
Mexico & 0.97 & -1.68 & 2.55 & $-61.40^{* * *}$ & $-61.43 * * *$ & $-61.31 * * *$ \\
Brazil & -0.73 & -2.35 & 0.76 & $-64.64 * * *$ & $-64.64 * * *$ & $-64.60^{* * *}$ \\
USA & -1.96 & -2.41 & 0.76 & $-69.31 * * *$ & $-69.36^{* * *}$ & $-69.28^{* * *}$ \\
Germany & -1.52 & -2.05 & 0.53 & $-62.74 * * *$ & $-62.73 * * *$ & $-62.73 * * *$ \\
Netherlands & -1.92 & -2.56 & -0.83 & $-61.41 * * *$ & $-61.41 * * *$ & $-61.42^{* * *}$ \\
\hline
\end{tabular}

Notes: $1 . * * *$ indicate the significant at $1 \%$ level.

2. C, C\&T and Non represent constant, constant and a time trend and without constant models.

\subsection{Empirical Implementation of the Spillover Index}

\subsubsection{Oil-Exporting Countries Spillovers}

The result of the degree and direction of return and volatility spillover within and across Brent oil and oil-exporting countries are show in Table 3. The total spillover index, given in the lower right corner of each panel, is computed as the average of the return and volatility spillovers from all other markets. This indicated that in the full sample, approximately $18.1 \%$ and $12.5 \%$ of the forecast error variance come from return and volatility spillovers. As can be observed is that volatility spillovers is weaker than return spillovers.

Table 3. Oil-exporting countries return and volatility spillovers

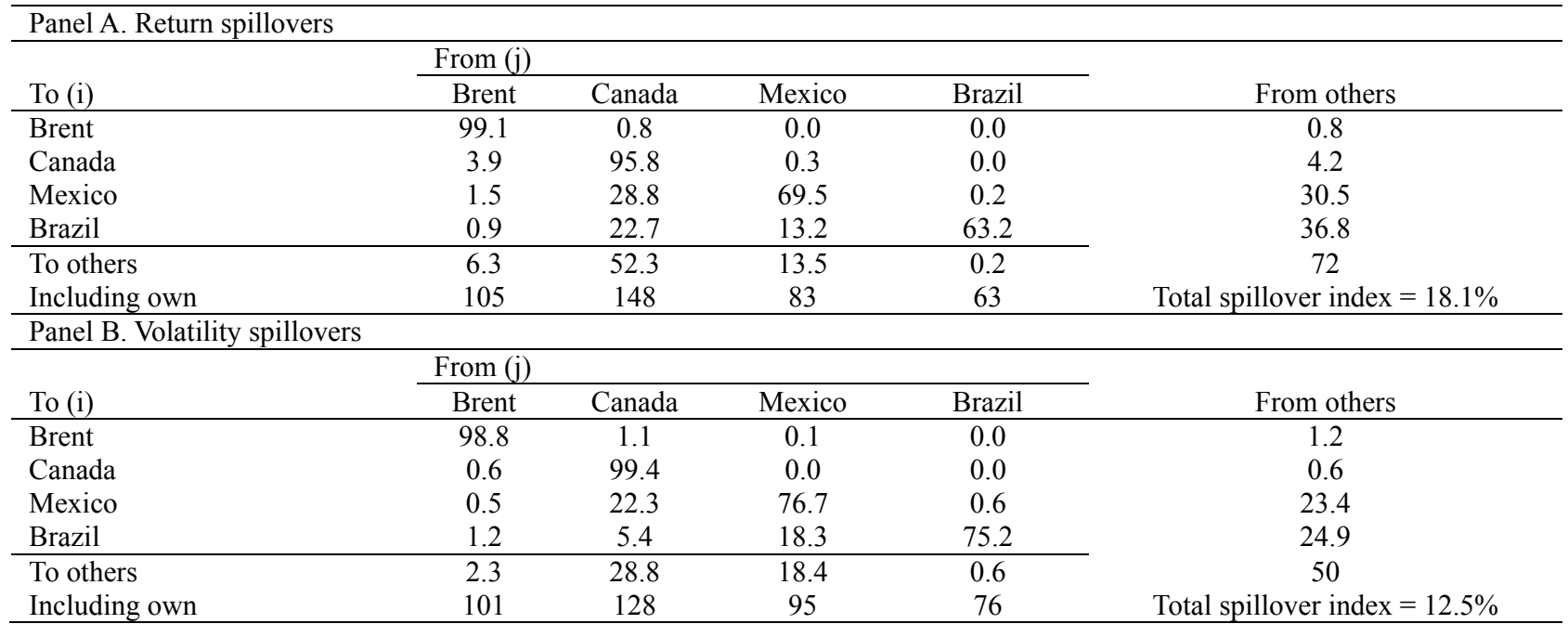

Panel A on Table 3 presents return spillovers, we find that Brazil is the most affected by others (37\%), and affecting other markets the most is Canada (52\%). Panel B shows that Brazil is the most affected by others as well (25\%), and affecting other markets the most is Canada (29\%). Hence, the result show Canada is the dominant market in return and volatility transmission, while Brazil is the dominant market in receiving return and volatility from all other markets. Although Brent oil contribution to others is very low, but its own-market spillovers very high. Canada had the most significant impact on Brent oil among oil-exporting countries $(0.8 \%)$.

\subsubsection{Oil-Importing Countries Spillovers}

The average of the total spillover index from Brent oil and all oil-importing countries in Table 4, is computed as the average of the return and volatility spillovers from all other markets. As can be observed is that return spillover $(28.6 \%)$ is higher than volatility spillovers $(27.5 \%)$. 
Table 4. Oil-importing countries return and volatility spillovers

\begin{tabular}{|c|c|c|c|c|c|}
\hline \multicolumn{6}{|c|}{ Panel A. Return spillovers } \\
\hline \multirow[b]{2}{*}{ To (i) } & \multicolumn{4}{|c|}{ From (j) } & \multirow[b]{2}{*}{ From others } \\
\hline & Brent & USA & Germany & Netherlands & \\
\hline Brent & 99.3 & 0.4 & 0.2 & 0.1 & 0.7 \\
\hline USA & 0.7 & 98.9 & 0.2 & 0.2 & 1.1 \\
\hline Germany & 1.5 & 38.5 & 59.6 & 0.4 & 40.4 \\
\hline Netherlands & 2.2 & 36.1 & 33.9 & 27.9 & 72.2 \\
\hline To others & 4.4 & 75 & 34.3 & 1 & 114 \\
\hline Including own & 104 & 174 & 94 & 28 & Total spillover index $=28.6 \%$ \\
\hline \multicolumn{6}{|c|}{ Panel B. Volatility spillovers } \\
\hline \multicolumn{5}{|c|}{ From $(j)$} & \multirow[b]{2}{*}{ From others } \\
\hline To (i) & Brent & USA & Germany & Netherlands & \\
\hline Brent & 98.6 & 1.3 & 0.1 & 0.0 & 1.4 \\
\hline USA & 1.1 & 94.4 & 0.2 & 4.3 & 5.6 \\
\hline Germany & 1.3 & 36.6 & 61.1 & 1.0 & 38.9 \\
\hline Netherlands & 2.8 & 24.7 & 36.8 & 35.7 & 64.3 \\
\hline To others & 5.2 & 62.6 & 37.1 & 5.3 & 110 \\
\hline Including own & 104 & 157 & 98 & 41 & Total spillover index $=27.5 \%$ \\
\hline
\end{tabular}

Panel A presents the return spillovers, we find that Netherlands is the most affected by others (72\%), and affecting other markets the most is USA (75\%). Panel B shows that Netherlands is the most affected by others (64.3\%), and affecting other markets the most is USA (62.6\%) as well. Hence, the result show USA is the dominant market in return and volatility transmission, while Netherlands is the dominant market in receiving return and volatility from all other markets. Although Brent oil contribution to others is very low, but its own-market spillover is very high.

The contributions of the oil market to oil-importing countries is $(0.7+1.5+2.2)$, and the effect of oil-importing countries on Brent oil is $(0.4+0.2+0.1)$, which is lower than the contributions of oil-importing countries.

\subsubsection{Spillovers among Brent Oil, Oil-Exporting and Oil-Importing Countries}

Table 5 provides details of the return and volatility spillovers over all variables in the system. (Note 10) The total return and volatility spillovers index are $35.1 \%$ and $31.3 \%$. In other words, $35 \%$ and $31 \%$ of forecast error variance in all markets are explained by spillovers across markets. We find that Netherlands market is the most affected by others $(73 \%)$, and Canada affecting other markets the most $(159 \%)$. The result indicate that, Netherlands is the dominate markets in receiving return from all other markets, and Canada is the dominant market in return transmission to all other markets.

Observed each variable variance decomposition in detail, it allows to examine how much of the forecast error variance of each variable can be explained by exogenous shocks to the other variables. First, Brent oil shocks by own is greater than shocks by other markets. The contribution from oil-exporting and importing countries to Brent oil market are $0.8 \%(0.8+0.0+0.0)$ and $0.5 \%(0.0+0.3+0.2)$, separately. The contribution from Brent oil market to oil-exporting and importing countries are $6.2 \%(3.8+1.5+0.9)$ and $4.4 \%(0.8+1.5+2.1)$, separately. The result shows that oil-exporting and importing countries was affected by Brent oil, especially had a high impact on Canada (4\%). Moreover, the impact of Canada on crude oil is the largest of the six countries (1\%). In addition, Canada's contribution on other countries are relatively lower than contribution on its own, but only the impact on US was up to $47.9 \%$. According to EIA report, nearly $69 \%$ of US crude oil imports originated from five countries in 2011, and Canada alone accounted for $25 \%$, become the largest exporter of crude oil to the US. In summary, oil markets especially have a high impact on Canada, and Canada has dominant spillover on other markets. We conjecture that the Brent oil indirectly spillovers on other countries through Canada. According to CIA World Factbook, Canada is the world's tenth-largest oil exporter, sixth-largest in oil production, and third-largest in oil exploration in the world. The statistic indicate that Canadian oil could become more important than ever. Canada is emerging as an important player in the world economy. Thus explain Canada has significantly impact on other countries. 
Table 5. Brent oil, oil-exporting and oil-importing countries return and volatility spillovers

\begin{tabular}{|c|c|c|c|c|c|c|c|c|}
\hline \multicolumn{9}{|c|}{ Panel A. Return spillovers index } \\
\hline \multirow{3}{*}{ To (i) } & \multicolumn{7}{|c|}{ From (j) } & \multirow{3}{*}{ From others } \\
\hline & Oil & \multicolumn{3}{|c|}{ Oil-exporting countries } & \multicolumn{3}{|c|}{ Oil-importing countries } & \\
\hline & Brent & Canada & Mexico & Brazil & USA & Germany & Netherlands & \\
\hline Brent & 98.6 & 0.8 & 0.0 & 0.0 & 0.0 & 0.3 & 0.2 & 1.3 \\
\hline Canada & 3.8 & 95.3 & 0.3 & 0.0 & 0.3 & 0.0 & 0.2 & 4.6 \\
\hline Mexico & 1.5 & 28.8 & 69.3 & 0.2 & 0.1 & 0.0 & 0.2 & 30.8 \\
\hline Brazil & 0.9 & 22.7 & 13.2 & 63.0 & 0.0 & 0.1 & 0.2 & 37.1 \\
\hline USA & 0.8 & 47.9 & 5.6 & 0.9 & 44.4 & 0.3 & 0.1 & 55.6 \\
\hline Germany & 1.5 & 29.8 & 3.2 & 0.5 & 8.7 & 55.9 & 0.4 & 44.1 \\
\hline Netherlands & 2.1 & 28.8 & 3.3 & 0.6 & 7.5 & 30.1 & 27.5 & 72.4 \\
\hline To others & 10.6 & 158.8 & 25.6 & 2.2 & 16.6 & 30.8 & 1.3 & 245.9 \\
\hline Including own & 109.2 & 254.1 & 94.9 & 65.2 & 61.0 & 86.7 & 28.8 & Total spillover \\
\hline Spillover flow & 11.9 & 163.4 & 56.4 & 39.3 & 72.2 & 74.9 & 73.7 & inde $x=35.1 \%$ \\
\hline \multicolumn{9}{|c|}{ Panel B. Volatility spillovers index } \\
\hline \multirow{3}{*}{ To (i) } & \multicolumn{7}{|c|}{ From (j) } & \multirow{3}{*}{ From others } \\
\hline & Oil & \multicolumn{3}{|c|}{ Oil-exporting countries } & \multicolumn{3}{|c|}{ Oil-importing countries } & \\
\hline & Brent & Canada & Mexico & Brazil & USA & Germany & Netherlands & \\
\hline Brent & 98.6 & 1.1 & 0.1 & 0.0 & 0.1 & 0.0 & 0.0 & 1.3 \\
\hline Canada & 0.8 & 98.2 & 0.0 & 0.0 & 0.1 & 0.1 & 0.8 & 1.8 \\
\hline Mexico & 0.5 & 22.3 & 76.3 & 0.5 & 0.0 & 0.3 & 0.0 & 23.6 \\
\hline Brazil & 1.2 & 5.3 & 18.3 & 75.2 & 0.0 & 0.0 & 0.0 & 24.8 \\
\hline USA & 0.7 & 51.8 & 3.7 & 0.0 & 39.9 & 0.2 & 3.7 & 60.1 \\
\hline Germany & 1.4 & 23.0 & 3.1 & 0.0 & 12.9 & 58.7 & 0.9 & 41.3 \\
\hline Netherlands & 2.6 & 18.0 & 1.6 & 0.3 & 7.6 & 35.7 & 34.2 & 65.8 \\
\hline To others & 7.2 & 121.5 & 26.8 & 0.8 & 20.7 & 36.3 & 5.4 & 218.7 \\
\hline Including own & 105.8 & 219.7 & 103.1 & 76.0 & 60.6 & 95.0 & 39.6 & Total spillover \\
\hline Spillover flow & 8.5 & 123.3 & 50.4 & 25.6 & 80.8 & 77.6 & 71.2 & index $=31.3 \%$ \\
\hline
\end{tabular}

Note: Spillover flow is the sum of $S_{j \rightarrow i}^{g}(H)$ and $S_{i \rightarrow j}^{g}(H)$

Furthermore, the study calculates the oil-exporting countries return and volatility spillovers over to the importing countries are $121 \%$ (Note 11 ) and $102 \%$, and the oil-importing countries return and volatility spillovers over to the exporting countries is $1.1 \%$ (Note 12) and $1 \%$. It is evident that oil-exporting countries have had significant impact on returns and volatilities of oil-importing countries.

Table 6 presents the net spillovers for each pair of variables. Panel A shows only Canada (154\%) and Brent (9\%) oil have positive total net spillovers, and Mexico, Brazil, Germany, USA and Netherlands have negative total net spillovers. In Panel B, Canada (120\%), Brent oil (6\%) and Mexico (3\%) have positive total net spillovers, and others countries have negative total net spillovers. Thus, Brent oil and Canada had dominant spillover on other markets, and Netherlands and USA are affected by others the most.

Table 6. Brent oil, oil-exporting and oil-importing countries net spillovers

\begin{tabular}{|c|c|c|c|c|c|c|c|c|c|}
\hline \multicolumn{10}{|c|}{ Panel A. Return net spillover } \\
\hline & Brent & Canada & Mexico & Brazil & USA & Germany & Netherlands & $\begin{array}{l}\text { Total net } \\
\text { spillover }\end{array}$ & Rank \\
\hline Brent & 0.0 & 3 & 1.5 & 0.9 & 0.8 & 1,2 & 1.9 & 9.3 & 2 \\
\hline Canada & $-\beta$ & 0.0 & 28.5 & 22.7 & 47.6 & 29.8 & 28.6 & 154.2 & 1 \\
\hline Mexico & -1.5 & -28.5 & 0.0 & 13 & 5.5 & 3.2 & 3.1 & -5.2 & 3 \\
\hline Brazil & -0.9 & -22.7 & -13 & 0.0 & 0.9 & 0.4 & 0.4 & -34.9 & 5 \\
\hline USA & -0.8 & -47.6 & -5.5 & -0.9 & 0.0 & 8.4 & 7.4 & -39 & 6 \\
\hline Germany & -1.2 & -29.8 & -1.2 & -0.4 & -8.4 & 0.0 & 29.7 & -13.3 & 4 \\
\hline Netherlands & -1.9 & -28.6 & -1.1 & -0.4 & -7.4 & -29.7 & 0.0 & -71.1 & 7 \\
\hline \multicolumn{10}{|c|}{ Panel B. Volatility net spillover } \\
\hline & Brent & Canada & Mexico & Brazil & USA & Germany & Netherlands & $\begin{array}{l}\text { Total net } \\
\text { spillover }\end{array}$ & Rank \\
\hline Brent & $\phi$ & -0.3 & 0.4 & 1.2 & 0.6 & 1.4 & 2.6 & 5.9 & 2 \\
\hline Canada & 0.3 & 0 & 22.3 & 5.3 & 51.7 & 22.9 & 17.2 & 119.7 & 1 \\
\hline Mexico & -0.4 & -22.3 & 0.0 & 17.8 & 3.7 & 2.8 & 1.6 & 3.2 & 3 \\
\hline Brazil & -1.2 & -5.3 & -17.8 & 0.0 & 0.0 & 0.0 & 0.3 & -24.0 & 5 \\
\hline USA & -0.6 & -51.7 & -3.7 & 0.0 & 0.0 & 12.7 & 3.9 & -39.4 & 6 \\
\hline Germany & $-1,4$ & -22.9 & -28 & 0.0 & -12.7 & 0.0 & 34.8 & -5.0 & 4 \\
\hline Netherlands & $-2 \mid 6$ & -17.2 & -1.6 & -0.3 & $-3 \mid 9$ & -34.8 & 0.0 & -60.4 & 7 \\
\hline
\end{tabular}


We also ranked the variables according to the net spillovers contribution. Based on the total net spillovers, Canada is the biggest net sender and also the largest potential spillover flow in the system (spillover flow see Table 5). The oil-importing countries are all net receivers. As shown in Panel B, Mexico becomes net sender of spillovers. German, Brazil and Netherlands are still the most vulnerable to potential contagion. Although Germany and Netherlands have negative net spillovers, their potential spillover flow are ranked second and third largest. We find that Brent oil is a net sender on the six countries, and Canada is a net sender on other countries except Brent oil. Moreover, oil-exporting countries are net sender on oil-importing countries as well.

\subsection{Dynamic Spillovers}

We summarized the major events which affecting the oil and stock markets during the period of the study, split them into before event and after event. (Note 13) This paper estimated the time-varying measure by using 200-day rolling samples and Figure 1 presented the dynamic behavior of the total return and volatility spillovers. The plot displays when major events occurs, the large variability in the total return and volatility spillover indices are observed.

For example, in the early 1990 s approximately $24 \%$ of shocks to stock index returns. Following the Asian crisis that started in 1997 and continued in 1998, return spillovers slightly toward 40\%. The impact of 9/11 terrorist attack in US raising the index by 7\%, and during 2006 to 2007 Chinese economic growth increased rather to $55 \%$. A year after, following the global financial crisis, the index jumped up to $62 \%$. However, during the European debt crisis of 2012 volatility spillovers surged substantially, reaching as high as $67 \%$. The paper finds that the total volatility spillover index is responsive to economic events.

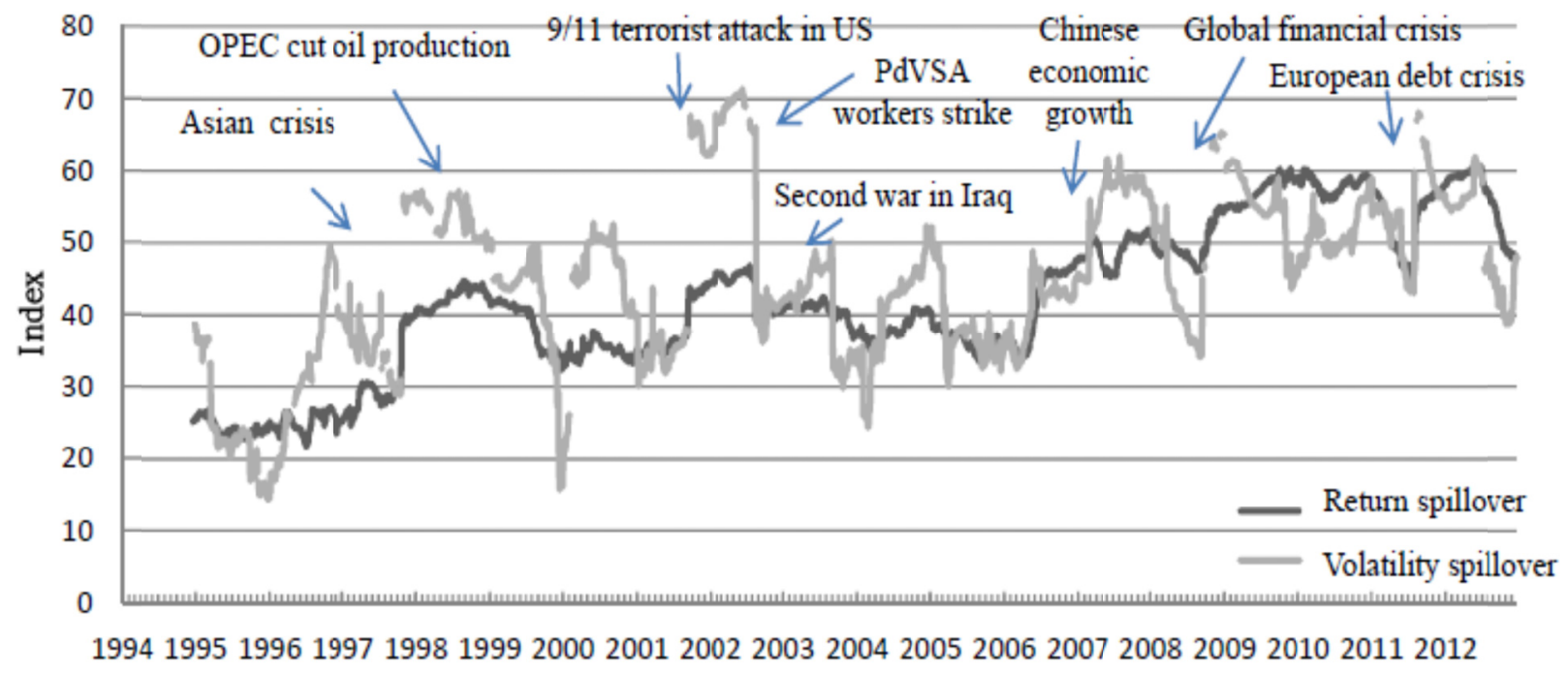

Figure 1. Spillover plot, Return spillovers and volatility spillovers

\subsection{Parametric and Nonparametric Test}

We split major events into before and after, and use parametric and nonparametric method to examine that the major events impact on dynamic of return and volatility spillovers between Brent oil market and stock markets present in Table 7. Panel A and B show that the magnitudes in after events are lower than before events. Only European debt crisis in Panel A is negative. Due to the interval between before European debt crisis and after global financial crisis are very close, so the test result might be affected slightly. The result of the $t$ and nonparametric tests provided significant evidence that after events are difference from before events. In other words, dynamic of return and volatility spillovers burst significantly during the major events. 
Table 7. Parametric and nonparametric test

\begin{tabular}{|c|c|c|c|c|c|c|c|}
\hline \multicolumn{8}{|l|}{ Panel A: Return spillover } \\
\hline Event & Before event & $\begin{array}{l}\text { After } \\
\text { event }\end{array}$ & $\begin{array}{c}\text { Before } \\
\text { event }(1)\end{array}$ & $\begin{array}{c}\text { After } \\
\text { event }(2)\end{array}$ & $\begin{array}{l}\text { Difference } \\
(2)-(1)\end{array}$ & T-test & $\begin{array}{c}\text { Nonparametric } \\
\text { test }\end{array}$ \\
\hline Asian crisis & $\begin{array}{c}1996 / 9 / 17-19 \\
97 / 6 / 30\end{array}$ & $\begin{array}{c}1997 / 7 / 2-1998 \\
/ 3 / 31\end{array}$ & 27.29 & 35.25 & 7.96 & $16.91 * * *$ & $138.31 * * *$ \\
\hline OPEC cut oil production & $\begin{array}{c}1997 / 3 / 5-199 \\
8 / 3 / 31\end{array}$ & $\begin{array}{c}1998 / 4 / 1-1999 \\
/ 4 / 29\end{array}$ & 33.48 & 42.64 & 9.17 & $24.79 * * *$ & $350.17 * * *$ \\
\hline 9/11 terrorist attack in US & $\begin{array}{c}2001 / 8 / 17-20 \\
01 / 9 / 6\end{array}$ & $\begin{array}{c}2001 / 9 / 10-200 \\
1 / 10 / 9\end{array}$ & 36.87 & 42.73 & 5.87 & $13.27 * * *$ & $19.86^{* * *}$ \\
\hline PdVSA workers strike & $\begin{array}{c}2001 / 12 / 3-20 \\
02 / 3 / 27\end{array}$ & $\begin{array}{c}2002 / 4 / 2-2002 \\
/ 7 / 12\end{array}$ & 44.99 & 45.46 & 0.47 & $4.13 * * *$ & $19.61 * * *$ \\
\hline Second war in Iraq & $\begin{array}{c}2002 / 6 / 27-20 \\
03 / 3 / 19\end{array}$ & $\begin{array}{c}2003 / 3 / 20-200 \\
3 / 11 / 28\end{array}$ & 40.91 & 41.45 & 0.53 & $7.57 * * *$ & $40.45 * * *$ \\
\hline $\begin{array}{l}\text { Chinese economic } \\
\text { growth }\end{array}$ & $\begin{array}{c}2005 / 3 / 3-200 \\
6 / 2 / 24\end{array}$ & $\begin{array}{c}2006 / 3 / 1-2007 \\
/ 3 / 6\end{array}$ & 36.04 & 43.22 & 7.19 & $21.22 * * *$ & $144.51 * * *$ \\
\hline Global financial crisis & $\begin{array}{c}2007 / 6 / 29-20 \\
08 / 7 / 31\end{array}$ & $\begin{array}{c}2008 / 8 / 1-2009 \\
/ 8 / 31\end{array}$ & 49.39 & 53.93 & 4.54 & $17.60 * * *$ & $160.47 * * *$ \\
\hline European debt crisis & $\begin{array}{c}2008 / 9 / 9-201 \\
0 / 10 / 29\end{array}$ & $\begin{array}{c}2010 / 11 / 1-201 \\
2 / 12 / 28\end{array}$ & 56.69 & 54.98 & -1.71 & $7.17 * * *$ & $16.45 * * *$ \\
\hline \multicolumn{8}{|l|}{ Panel B Volatility spillover } \\
\hline Asian crisis & $\begin{array}{c}1996 / 9 / 17-19 \\
97 / 6 / 30\end{array}$ & $\begin{array}{c}1997 / 7 / 2-1998 \\
/ 3 / 31\end{array}$ & 39.59 & 45.13 & 5.53 & $5.34 * * *$ & $7.55^{* * *}$ \\
\hline OPEC cut oil production & $\begin{array}{c}1997 / 3 / 5-199 \\
8 / 3 / 31\end{array}$ & $\begin{array}{c}1998 / 4 / 1-1999 \\
/ 4 / 29\end{array}$ & 42.11 & 50.60 & 8.49 & $10.78 * * *$ & $40.48 * * *$ \\
\hline 9/11 terrorist attack in US & $\begin{array}{c}2001 / 8 / 17-20 \\
01 / 9 / 6\end{array}$ & $\begin{array}{c}2001 / 9 / 10-200 \\
1 / 10 / 9\end{array}$ & 37.04 & 59.92 & 22.88 & $7.73 * * *$ & $14.27 * * *$ \\
\hline PdVSA workers strike & $\begin{array}{c}2001 / 12 / 3-20 \\
02 / 3 / 27\end{array}$ & $\begin{array}{c}2002 / 4 / 2-2002 \\
/ 7 / 12\end{array}$ & 65.06 & 70.04 & 4.98 & $14.62 * * *$ & $89.76^{* * *}$ \\
\hline Second war in Iraq & $\begin{array}{c}2002 / 6 / 27-20 \\
03 / 3 / 19\end{array}$ & $\begin{array}{c}2003 / 3 / 20-200 \\
3 / 11 / 28\end{array}$ & 41.77 & 45.39 & 3.61 & $17.63 * * *$ & $122.99 * * *$ \\
\hline $\begin{array}{l}\text { Chinese economic } \\
\text { growth }\end{array}$ & $\begin{array}{c}2005 / 3 / 3-200 \\
6 / 2 / 24\end{array}$ & $\begin{array}{c}2006 / 3 / 1-2007 \\
/ 3 / 6\end{array}$ & 36.34 & 42.25 & 5.90 & $17.75^{* * *}$ & $168.13^{* * *}$ \\
\hline Global financial crisis & $\begin{array}{c}2007 / 6 / 29-20 \\
08 / 7 / 31\end{array}$ & $\begin{array}{c}2008 / 8 / 1-2009 \\
/ 8 / 31\end{array}$ & 51.13 & 54.42 & 3.29 & $4.01 * * *$ & $15.49 * * *$ \\
\hline European debt crisis & $\begin{array}{c}2008 / 9 / 9-201 \\
0 / 10 / 29\end{array}$ & $\begin{array}{c}2010 / 11 / 1-201 \\
2 / 12 / 28\end{array}$ & 54.14 & 55.48 & 1.34 & $3.18^{* * *}$ & $13.85 * * *$ \\
\hline
\end{tabular}

Note: $* * *$ indicate the significant at $1 \%$ level.

\section{Conclusions}

This study examine return and volatility spillovers effects between Brent oil market and stock markets (comparing oil market with both stock markets of oil-exporting and oil-importing countries together and individually) by applied new spillover index approach.

The paper provides evidence that oil-exporting countries have had significant impact on returns and volatilities of oil-importing countries, which stock market in Canada is the dominant net sender and stock market in Netherland is the dominant net receiver. Second, the oil market spillover on oil-exporting markets more than oil-importing markets in terms of both returns and volatilities, especially oil markets had a high impact on Canada. Moreover, stock market in Canada had dominant spillover on other markets. We conjecture that Brent oil market indirect spillover on other countries through Canada. Third, the net direction return and volatility spillovers from Brent oil to the six countries are net spillovers sent, and from oil-exporting countries to oil-importing countries are net spillovers sent as well. Finally, the result shows that the dynamic of spillovers burst significantly during the major events.

\section{References}

Akoum, I., Graham, M., Kivihaho, J., Nikkinen, J., \& Omran, M. (2012). Co-movement of oil and stock prices in the GCC region: A wavelet analysis. The Quarterly Review of Economics and Finance, 52(4), 385-394. http://dx.doi.org/10.1016/j.qref.2012.07.005

Alter, A., \& Beyer, A. (2014). The dynamics of spillover effects during the European sovereign debt turmoil. Journal of Banking \& Finance, 42, 134-153. http://dx.doi.org/10.1016/j.jbankfin.2014.01.030 
Arouri, M. E. H., Jouini J., \& Nguyen, D. K. (2011). Volatility spillovers between oil prices and stock sector returns: Implications for portfolio management. Journal of International Money and Finance, 30(7), 1387-1405. http://dx.doi.org/10.1016/j.jimonfin.2011.07.008

Arouri, M. E. H., Lahiani, A., \& Nguyen, D. K. (2011). Return and volatility transmission between world oil prices and stock markets of the GCC countries. Economic Modelling, 28(4), 1815-1825. http://dx.doi.org/10.1016/j.econmod.2011.03.012

Awartani, B., \& Maghyereh, A. I. (2013). Dynamic spillovers between oil and stock markets in the Gulf Cooperation Council Countries. Energy Economics, 36, 428-42. http://dx.doi.org/10.1016/j.eneco.2012.11.024

Basher, S. A., \& Sadorsky, P. (2006). Oil price risk and emerging stock markets. Global Finance Journal, 17(2), 224-251. http://dx.doi.org/10.1016/j.gfj.2006.04.001

Chang, C. L., McAleer, M., \& Tansuchat, R. (2013). Conditional correlations and volatility spillovers between crude oil and stock index returns. The North American Journal of Economics and Finance, 25, 116-138. http://dx.doi.org/10.1016/j.najef.2012.06.002

Claeys, P., \& Vašíček, B. (2012). Measuring sovereign bond spillover in Europe and the impact of rating news. Working Paper.

Conraria, L. A., \& Wen, Y. (2012). OPEC's oil exporting strategy and macroeconomic (in) stability. Energy Economics, 34(1), 132-136. http://dx.doi.org/10.1016/j.eneco.2011.03.014

Diebold, F. X., \& Yilmaz, K. (2009). Equity market spillovers in the Americas. Journal Economia Chilena, 12(2), $55-65$.

Diebold, F. X., \&Yilmaz, K. (2009). Measuring financial asset return and volatility spillovers, with application to global equity markets. The Economic Journal, 119, 158-171. http://dx.doi.org/10.1111/j.1468-0297.2008.02208.x

Diebold, F. X., \& Yilmaz, K. (2012). Better to give than to receive: predictive directional measurement of volatility spillovers. International Journal of Forecasting, 28(1), 57-66. http://dx.doi.org/10.1016/j.ijforecast.2011.02.006

Du, L., He, Y., \& Wei, C. (2010). The relationship between oil price shocks and China's macro-economy: an empirical analysis. Energy Policy, 38(8), 4142-4151. http://dx.doi.org/10.1016/j.enpol.2010.03.042

Filis, G., Degiannakis, S., \& Floros, C. (2011). Dynamic correlation between stock market and oil prices: The case of oil-importing and oil-exporting countries. International Review of Financial Analysis, 20(3), 152-164. http://dx.doi.org/10.1016/j.irfa.2011.02.014

Guesmi, K., \& Fattoum, S. (2014). Return and volatility transmission between oil prices and oil-exporting and oil-importing countries. Economic Modelling, 38, 305-310. http://dx.doi.org/10.1016/j.econmod.2014.01.022

Hammoudeh, S., \& Choi, K. (2006). Behavior of GCC stock markets and impacts of US oil and financial markets. Research in International Business and Finance, 20(1), 22-44. http://dx.doi.org/10.1016/j.ribaf.2005.05.008

Hammoudeh, S., Dibooglu, S., \& Aleisa, E. (2004). Relationships among U.S. oil prices and oil industry equity indices. International Review of Economics \& Finance, 13(4), 427-453. http://dx.doi.org/10.1016/S1059-0560(03)00011-X

Jammazi, R. (2012). Oil shock transmission to stock market returns: Wavelet-multivariate Markov switching GARCH approach. Energy, 37(1), 430-454. http://dx.doi.org/10.1016/j.energy.2011.11.011

Jin, X., Lin, S. X., \& Tamvakis, M. (2012). Volatility transmission and volatility impulse response functions in crude oil markets. Energy Economics, 50(4), 2125-2134. http://dx.doi.org/10.1016/j.eneco.2012.03.003

Jouini, J. (2013). Return and volatility interaction between oil prices and stock markets in Saudi Arabia. Journal of Policy Modeling, 35(6), 1124-1144. http://dx.doi.org/10.1016/j.jpolmod.2013.08.003

Kilian, L., \& Park, C. (2009). The Impact of Oil Price Shocks on the U.S. Stock Market. International Economic Review, 50(4), 1267-1287. http://dx.doi.org/10.1111/j.1468-2354.2009.00568.x

Lescaroux, F., \& Mignon, V. (2008). On the influence of oil prices on economic activity and other macroeconomic and financial variables. OPEC Energy Review, 32(4), 343-380. http://dx.doi.org/10.1111/j.1753-0237.2009.00157.x

Maghyereh, A. (2004). Oil price shocks and emerging stock markets: A generalized VAR approach. International 
Journal of Applied Econometrics and Quantitative Studies, 1(2), 27-40.

Maghyereh, A., \& Al-Kandari, A. (2007). Oil prices and stock markets in GCC countries: new evidence from nonlinear cointegration analysis. Managerial $\quad$ Finance, 33(7), 449-460. http://dx.doi.org/10.1108/03074350710753735

Malik, F., \& Ewing, B. T. (2009). Volatility transmission between oil prices and equity sector returns. International Review of Financial Analysis, 18(3), 95-100. http://dx.doi.org/10.1016/j.irfa.2009.03.003

Malik, F., \& Hammoudeh, S. (2007). Shock and volatility transmission in the oil, US and Gulf equity markets. International Review of Economics \& Finance, 16(3), 357-368. http://dx.doi.org/10.1016/j.iref.2005.05.005

Miller, J. I., \& Ratti, R. A. (2009). Crude oil and stock markets: Stability, instability, and bubbles. Energy Economics, 31(4), 559-568. http://dx.doi.org/10.1017/CBO9781107109957.019

Morana, C. (2013). Oil price dynamics, macro-finance interactions and the role of financial speculation. Journal of Banking \& Finance, 37(1), 206-226. http://dx.doi.org/10.1016/j.jbankfin.2012.08.027

Nandha, M., \& Faff, R. (2008). Does oil move equity prices? A global view. Energy Economics, 30(3), 986-997. http://dx.doi.org/10.1016/j.eneco.2007.09.003

Onour, I. A. (2007). Impact of oil price volatility on Gulf Cooperation Council stock markets' return. OPEC Review, 31(3), 171-189. http://dx.doi.org/10.1111/j.1468-0076.2007.00182.x

Park, J., \& Ratti, R. A. (2008). Oil price shocks and stock markets in the U.S. and 13 European countries. Energy Economics, 30(5), 2587-2608. http://dx.doi.org/10.1016/j.eneco.2008.04.003

Yilmaz, K. (2009). Business Cycle Spillovers. Koc University-TUSIAD Economic Research Forum Working Papers.

Yilmaz, K. (2010). Return and volatility spillovers among the East Asian equity markets. Journal of Asian Economics, 21(3), 304-313. http://dx.doi.org/10.1016/j.asieco.2009.09.001

Zarour, B. A. (2006). Wild oil prices, but brave stock markets! The case of GCC stock markets. Operational Research, 6(2), 145-162. http://dx.doi.org/10.1007/BF02941229

Zhou, X., Zhang, W., \& Zhang, J. (2012). Volatility spillovers between the Chinese and world equity markets. Pacific-Basin Finance Journal, 20(2), 247-270. http://dx.doi.org/10.1016/j.pacfin.2011.08.002

\section{Notes}

Note 1. In term of return spillover, Basher and Sadorsky (2006), Nandha and Faff (2008), Park and Ratti (2008), Maghyereh (2004) and Hammoudeh and Choi (2006) etc. In term of volatility spillover, Hammoudeh et al. (2004), Malik and Hammoudeh (2007) and Malik and Ewing (2009) so on.

Note 2. Hammoudeh and Choi (2006), Zarour (2006), Maghyereh and Al-Kandari (2007); Onour (2007); Arouri, Lahiani and Nguyen (2011) and Awartani and Maghyereh (2013).

Note 3. Basher and Sadorsky (2006), Kilian and Park (2009), Malik and Ewing (2009), Miller and Ratti (2009), Aguiar-Conraria and Wen (2012), Arouri, Jouini and Nguyen (2012), Jammazi (2012) and Jin et al. (2012).

Note 4. Arouri, Lahiani and Nguyen (2011), Chang, McAleer and Tansuchat (2012) and Arouri, Jouini and Nguyen (2011) etc.

Note 5. First, the method can not only measure the magnitude of the spillover in return and volatility, it can also indicate the direction of the spillover. Second, the method measures the shocks to return and volatility of one market on any market, and net contribution of one market to any set of markets. Third, the intensity of spillovers is vary over time, the method can track time variation in spillovers via rolling window estimation.

Note 6. Diebold and Yilmaz (2008), Diebold and Yilmaz (2009), Yilmaz (2010) and Zhou, Zhang and Zhang (2012) analyzed the international stock markets. Yilmaz (2009) studied business cycle interdependence among industrial countries. Diebold and Yilmaz (2012) explore the volatility spillovers across American stock, bond, foreign exchange and commodities markets. Awartani and Maghyereh (2013) investigated the dynamic spillover return and volatility between oil and equities in the GCC countries. Claeys and Vašíček (2012) analyzed EU sovereign bond spreads relative to the German Bund. Alter and Beyer (2012) analyzed spillovers between sovereign credit markets and banks in the euro area.

Note 7. For example, Akoum et al. (2012) noted an increasing strength in the market dependencies after 2007. 
Awartani and Maghyereh (2013) find there are bi-directional spillovers between the oil and stock markets, and the trends were more pronounced in the aftermath of the Global Financial Crisis in 2008. Morana (2013) find macroeconomic shocks actually largely account for the 2007-2008 oil price swing. Few studies cover the major economic events over the period of study. Filis, Degiannakis and Floros (2011) tied up specific oil price shocks events, and find time-varying correlations depend on the origin of the oil shocks.

Note 8 . The sample that we set are according to EIA report. Canada exported $1.57 \mathrm{million} \mathrm{bbl} / \mathrm{d}$ and also is the third largest oil exporter outside OPEC. Mexico exported about 1.34million bbl/d in 2011, crude oil accounted for 2.55 million bbl/d, which is a major non-OPEC oil producer. Brazil exported about half a million bbl/d in 2011. In regard to oil-importing countries, US is the world's biggest importer of crude oil with imported of 7.44 million bbl/d. Germany is not only the largest energy consumer in Europe, excluding Russia, but also the seventh largest energy consumer which imported of 2.22 million bbl/d. Finally, Netherlands imported about 1 million bbl/d which accounted for about 50 percent of domestic energy consumption.

Note 9. In order to measure volatility we do not use efficient range-based volatility estimate which was first proposed by Garman and Klass (1980), because we use Europe Brent spot price data from EIA.

Note 10. Table 5 shows the shock feed from row variables to column variables. The spillover effects of an impulse to the variables shows in the first column of each row. The responding variables are on the top row. The total spillover sent $\left(S_{i \rightarrow j}^{g}(H)\right)$ are aggregate in the last column, and the total spillover received $\left(S_{j \rightarrow i}^{g}(H)\right)$ are aggregate on the bottom row. Table 5 also can be divided into four quadrants presents spillover effect: among oil-exporting countries (top-left), among oil-importing countries (bottom-right), from oil-importing to oil-exporting countries (top-right) and from oil-exporting to oil-importing countries (bottom-left).

Note 11. Calculate the return spillovers from oil-exporting countries to oil-importing countries $(47.9 \%+29.8 \%+28.8 \%+5.6 \%+3.2 \%+3.3 \%+0.9 \%+0.5 \%+0.6 \%)$

Note 12. Calculate the return spillovers from oil-importing countries to oil-exporting countries $(0.3 \%+0.1 \%+0.1 \%+0.2 \%+0.2 \%+0.2 \%)$

Note 13. First, the Asian crisis took place in mid-1997 to early 1998, the oil prices went down because of the reduction in demand. The majority of stock markets were also decline in that period. During March 1998 and March 1999, OPEC embarked on two production cuts. The September 11, 2011 terrorist attacks in the US. Venezuela's state oil firm PDVSA workers strike brought the country's oil industry to a halt from April 2002. The second war in Iraq started in March 2003, caused oil price increase significantly but the stock market react opposite. In 2006, as China's economic growth rising demand, led to the oil prices increased significantly. During 2008 and 2009 the global financial crisis began when the US subprime mortgage market collapsed, the crisis had worsened as stock markets around the globe crashed, and caused oil prices to decline heavily. Finally, the European sovereign debt crisis started in Greece and spread to primarily Spain, Portugal, Ireland and Italy during 2009. Stock market crash causing financial turmoil and decline in confidence, and the oil prices also fell sharply. 